\title{
G $\mathbb{R}^{\mathrm{E}} \mathrm{EN}$
}

Buading in the Larva of Pectinatella

Zaology

A. M.

1910 

\&

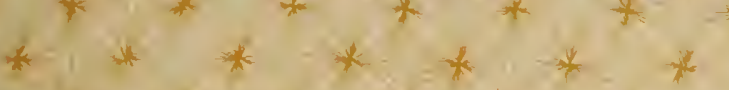

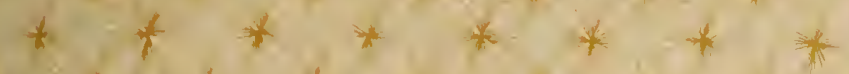

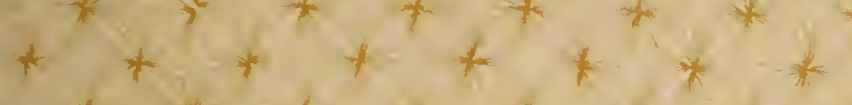

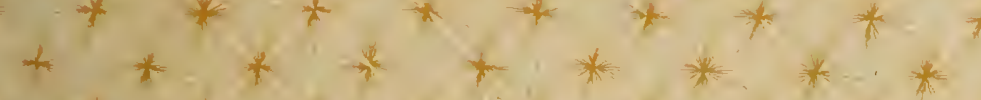

$* * * *^{*}+* * * * * *$

$+* *+* *+*+*$

$* * * * * *+4$

$x^{*}+x^{*} *$

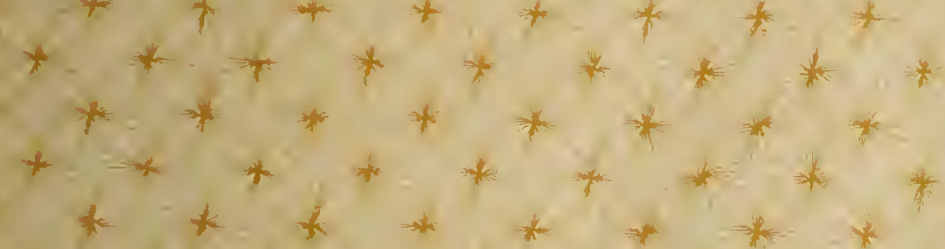

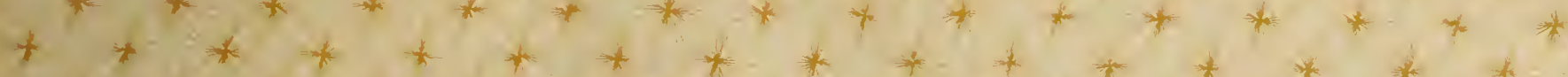

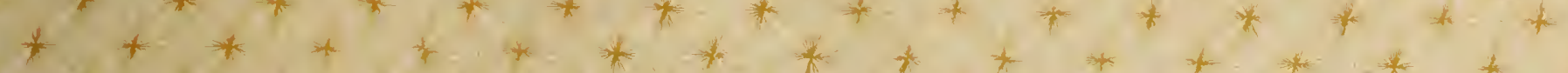

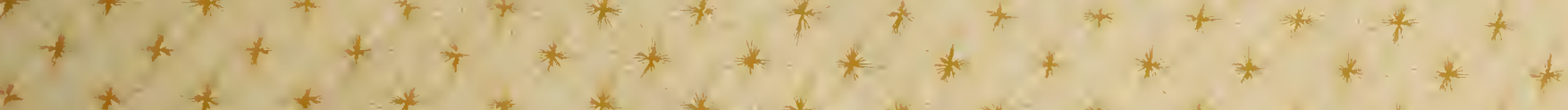

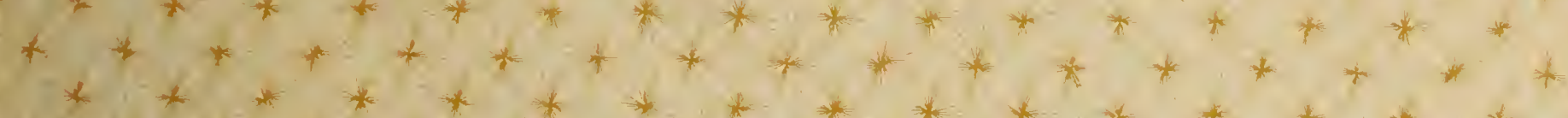

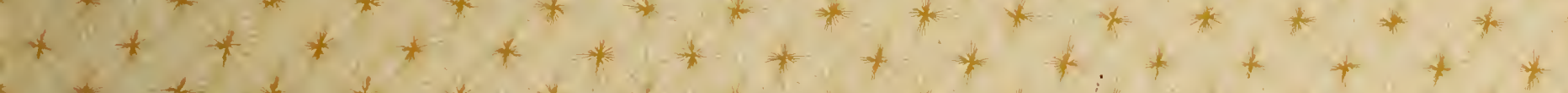

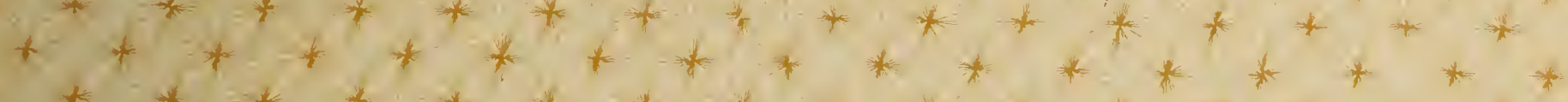

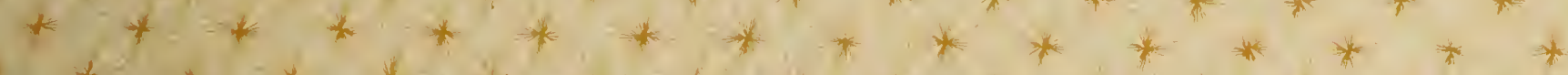

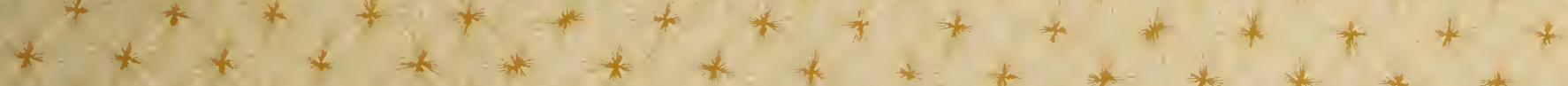

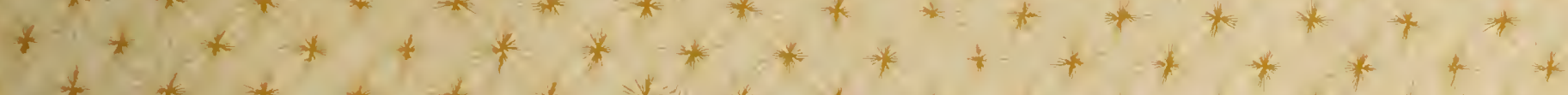

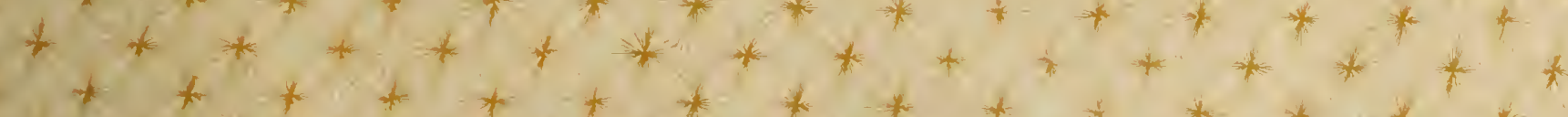

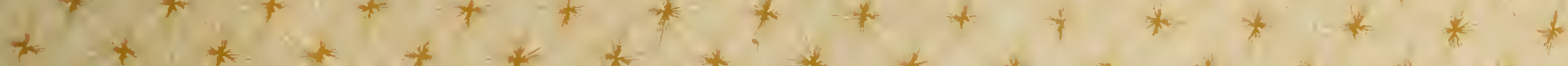

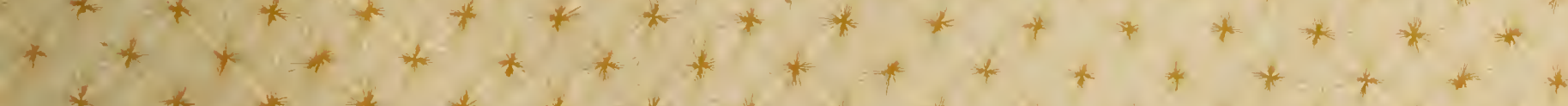

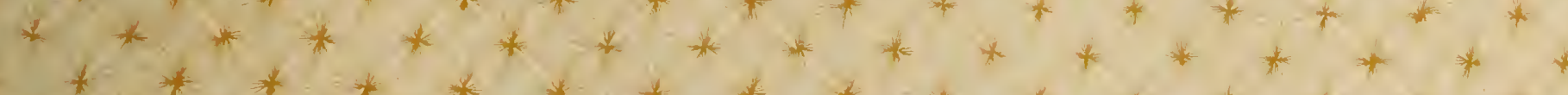

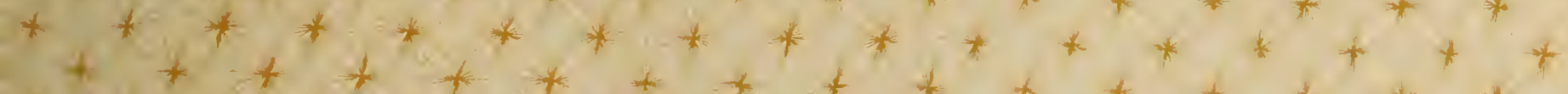

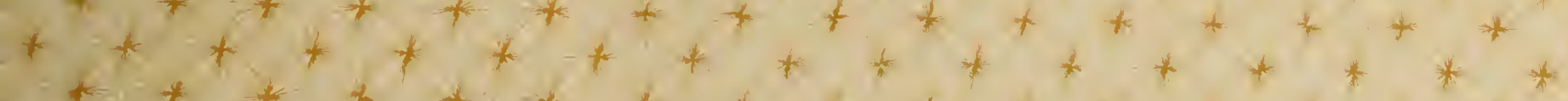

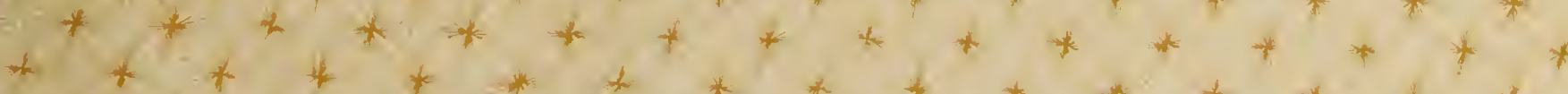

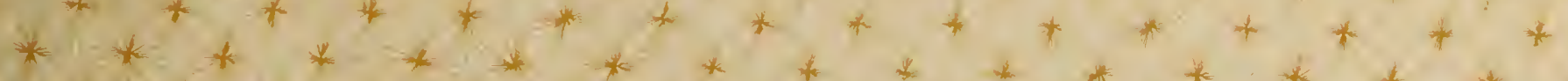
$* * * * * * * * * * * * * * * * * * * * *+*$

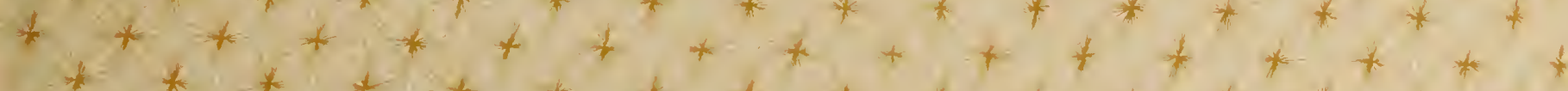

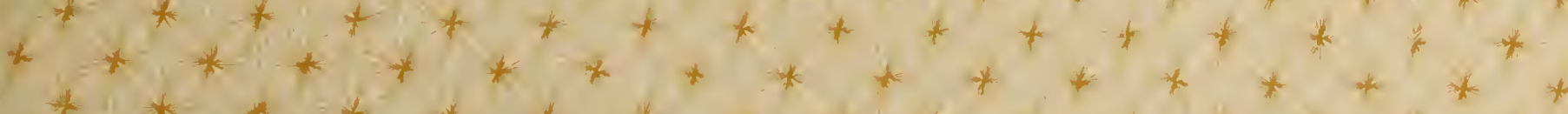

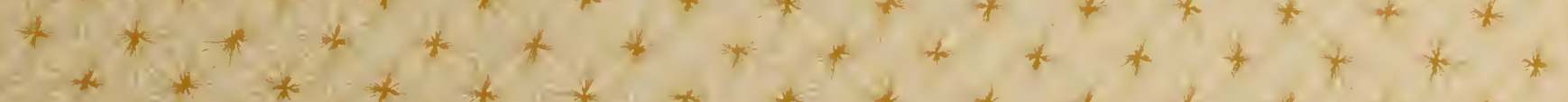

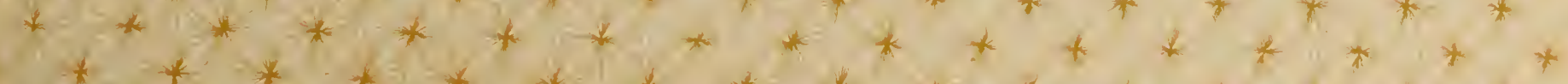


Digitized by the Internet Archive in 2013 


\section{BUDDING IN THE LARVA OF PECTINATELLA}

BY

BESSIE ROSE GREEN

A. B. University of Illinois, 1907

THESIS

Submitted in Partial Fulfillment of the Requirements for the

Degree of

MASTER OF ARTS

IN ZOOLOGY

IN

THE GRADUATE SCHOOL

OF THE

UNIVERSITY OF ILLINOIS

$1910 \mathrm{~m}$ 



\section{UNIVERSITY OF ILLINOIS \\ THE GRADUATE SCHOOL}

I HEREBY RECOMMEND THAT THE THESIS PREPARED UNDER MY SUPERVISION BY

$$
\text { Bessie Rose Green }
$$

ENTITLED Budding in the Larva of Pectinatelia

BE ACCEPTED AS FULFILLING THIS PART OF THE REQUIREMENTS FOR THE

DEGREE OF Master of Arts

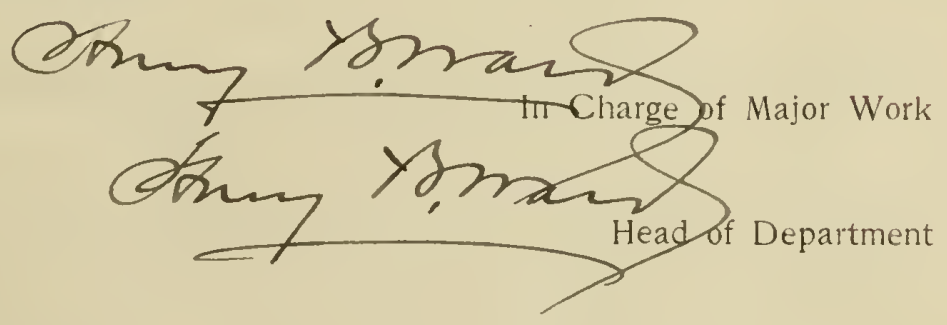

Recommendation concurred in:

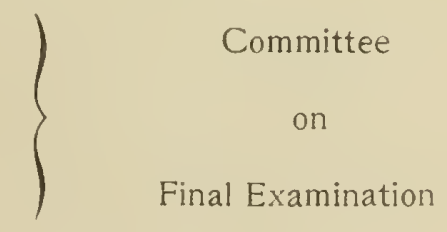





\section{INTRODUCTION.}

During the first week of Auglist, 1909, while working at the Illinols Blological Station at Havana, Illinols, Professor Smlth, who had charge of the station, called my attention to the free swlmming larva of Pectinatelia.

The larvar were first seen in a jar containing a little moss, and partly fllled with water whlch had been dipped from Quiver lake near 1 ts east shore. There were about a dozen of these forms sw1mming about in the water. After a careful examination, under the low power of the microscope, it was plainly seen that this free swimning form was a Bryozoan larva. In detail, 1 t differed from any Bryozoan larvae found in that region, previolisly. The next thing to determine was to what Bryozoan this larva belonged. All of the collections made that day were examined, and those in which Pectinatella colonies were present contained more of the free swimming larvae than others. The posstbillty of their being the larvae of this form was suggested, but thetr Identity had to be estabilshed for certain. The colonies were thoroughly washed, and placed in a jar of clear water, thus getting rid of the larvae that might have adhered to the colony. After a few minutes just as many larvae were seen swimming about, as had been observed before. By watching closely, they could be seen emerging from the colony. These observations established the fact, beyond a doubt, that the form under consideration was the free swimming larva of Pectinatelia.

Several excursions were made to the same region, the east shore of Qulver lake, where larvae and colontes were collected in great abundance. Before making the collections, the water in the 

neighborhood of the colonies was examined, and, as was expected, nunerous larvae were seen swimming about. Evidence points toward the fact that these larvae spend a part of the1r extstence as free swimming organisms.

The Pectinatella colonies were exceedingly numerous along the east shore of the lake in places over shadowed by trees. They grew on the trinks of trees and stems of water plants fust a few inches. below the surface of the water. The size of the colonies varled from small ones to those having a dianeter of eight or ten inches. In this same region the statoblasts of Pectinatella were. floating on the slirface of the water in large numbers.

The Iarvae were collected by straining the water throligh a fine net. The colonies, especially the older ones, were placed in Jars of clear water, and by shaking them gently the larvae that adhered to the surface, or had actually emerged from the colony, were soon free in the water. By straining, and repeating the process several times, larvae were collected in large quantities.

The method of killing and flxing was very simple. To prevent contractions calised by the kllling fluid, the larvae were placed first irto a dilute solution of chloretone. After a few minutes all movements had ceased. They were then transferred to a $0.1 \%$ solution of hot corrosive sublimate in which they remained for about five minutes. Other klling agents were lised, but this proved most successful. The stains that were most satisfactory for my work were Delafield"s and Thrlich's Haematoxylin with Aeld Fichsin used as a colnter stain. Paracarmine was lised for staining in toto.

A large number of the larvae were preserved, and brought to the University, where, under Dr.. Ward's charge, I made a study of 



\section{3.}

their structure, and also of the process of blidding.

The terminology is similar to that used by Davenport. Polypide is a term applied to the organs, taken as a whole, which are formed from a bud. If a plane be passed through the long axis of a polyplde between the mouth and anus, that part in winich the molith is located is the oral side, and the opposite one, containing the anus, is the anal siae. Coenocoel is the cavity of the larval sac. As far as I have been able to find out, the free swiming larva of Pectinatelia has not been described. In fact very little has been written concerning the Pectinatella colony.

Kraepelin refers to the larva, and flgures the ring fold. The larvae of other Bryozoans which are nearly related forms show structires that bear a decided resemblance to those of Pectinatella. The movement of this larva compares almost exactly to that of Plumatella as described by Braem.

Davenport's papers are useful for comparison in studying the process of budding. Although the process is not exactly the same in the two forms, yet it is comparable in many respects. 



\section{I. . THE LARVA.}

The free swiming larva of Pectinatella is a small wh1t1sh, pear shaped sac which is dome like at one end and more elongated and narrower at the other. It measures from 1 to $2 \mathrm{~m}$ in $1 \mathrm{n}$ length and $0,85 \mathrm{~m} \mathrm{~m}$ in w1dth. The wall of the sac is comparatively thin and somewhat transparent so the polypides may easily be seen throligh 1t. The larva looks like a tiny balloon when it is quiet in the water. The rounded dome is uppermost, while the narrower end which contains the polypides and buds is lowermost. The slirface of the dome is covered with cllla which vibrate very rapidiy. At the edge of the dome is a ring like fold which engirdles the larva. This fold had approximately the same position, and was of the same general appearance, th all of the larvae collected. The rest of the larva was witholi cilia.

In stidying the preserved material, 1t was found that the size and stage of development of the larvae varied considerably. Size cannot be considered as a criterion for the determination of the age of the larva. In many cases some of the smaller larvae contaln two or even four fully formed polypides, whlle larger larvae have only a few small buds developed. One or two larvae of average slze were collected and, on examination, proved to be larval sacs without any blids. The majorlty of the larvae contained folir well developed polypides beslaes several buds in various stages of development. There were four openings at the non-ciliated end of these larvae, through which the lophophores of the polypides could be protruded and retracted. A very conspicuous reddish-brown spot colild be seen at the base of the lopholpores in the living specimen. 

Fig. I represents a larva in which two polypides and two buds colid easily be seen. This is a drawing of a typical larva, and the general relation of parts is well represented here. A single polypide is represented in Fig. 2.

\section{Movement.}

The Iarva progresses by a slow uniform movenent which is accomplished by the action of the cilia that cover the dome shaped part of the larval sac. This part goes first in movement. When the larva remains quiet for a time the clliated part is uppermost, and Its long axis is in a vertical position. In moving in a horizontal plane the long axis is at a slight angle to that plane. The cillated part is fust a little higher than the opposite end. It swims abolit here and there as if in search of a place for attachment. The movement in general is in straight lines. Some of the larvae rested on the bottom of the Jar for a few minutes at a time and then proceeded, as before, in their random movements. The exact length of the period during which the larva remains free swimning was not determined, but all larvae under my observation had become attached at the end of twenty-four hours. only a few larvae that had become attached were collected, because conditions were unfavorable for their existence. The plan was to obtain a series of the earliest stages of development, taken a few hours apart. only two steps in the series were obtained, for conditions were slich that all of the larvae had disappeared at the end of the first day after they had become attached.

\section{WaIl of the Larva.}

The wall of the larval sac 1 s made lip of two layers of 

cells, the outer, ectoderm layer, and an inner layer which lines the coenocoel. In the dome shaped part the ectoderm is composed of c1llated, columnar cells which stain rather heavily. In the young larva, as is show in Flg. 3, these cells are all of abolit the same size, thus forming a smooth, even layer. The nuclet are rather large, and are located near the base of the cells. In the older larva, on the other hand, this layer presents several pecliliarities, as is represented in Fig. 6. In the first place, the cells have become very much elongated, thus making the layer wider. The inner half of the cells have expanded die to growth, and by so doing has Increased the inner slirface of this layer to slich an extent that $1 t$ forms many folds. A few vacuoles are found in the expanded part of the cells. Pecullar knoblike strictures are found on the outer surface of this layer in the older larvae. They are very small having a helght of about one-sixth that of the c1l1a. I was unable to make out the relation of these structures to the cells, but it was quite evident that they were projections from the surface of the ectoderm. They took on a reddish stain whlle the other structures stained blie. In some places, at least, it appeared as if a c1lium passed through each little projection, and extended down into the cell. They are found on the entire cillated surface of these older larvae. The ectoderm is composed of ciliated, columnar cells only as far as the edge of the ring fold. Here the character of liayer changes. There are no cllia present, and the part of this layer that forms the inner wall of the fold is composed of flattened cells. In what is termed the non-clllated region, the layer gradually becomes very much wider. The cells are very mich elongated, and the entire layer is highly vacuolated. 

The ring fold is a peculiar structure.

Its formation could

not be traced in the free swimming larva, since all of the material collected showed the ring fold in the same stage as that represented In Fig. 4. This flgure corresponds very closely with Kraepelin's figire of the ring fold of Pectinatella.

F18. 5 represents a section of the ectoderm in the non-ciliated region of the larval wall. The cell outlines are indistinct, and the nucle1 are not arranged in any definite order. In some cases the vacuoles have little strands of tissue passing through them, whlle in others there seems to be a substance, whlch stains lightly entirely filling the vacuoles.

The Inner layer of the wall of the larva lines the coenocoel and also the cavity of the ring fold. In the dome shaped part the cells are flattened, making the layer very narrow. After tracing It beyond the ring fold a short distance, the cells appear more rounded and closer together. The layer becomes more or less irregular where the cells are so numerous. Thls increase in the number of cells of this layer is more evident in young larvae than in older ones. It bears some relation to the formation of buds, for it $1 \mathrm{~s}$ only present in the region in which blids are formed.

\section{Origin of Buds.}

Buas origlnate in the non-ciliated region of the larval sac, and extend into the cav1ty. The dome shaped part of the larval wall does not contribute, in any way, toward the formation of the buds. The youngest stage in the development of the primary buds that was observed was in a larva where only two buds were present. They were located a short distance apart, and one was just a little smaller than the other. For the want of more data, I am unable to 

say whether they originated as a dolible blid or not. advanced the theory of dolible bliding as the way in which the primary polypides originate. Braem takes up the opposite view. It is quite evident that each blid formed bears a defintte relation to the blid near which it arises. Buds may arise in three ways, as a single blid some distance from an older one, as is represented in Fig. 9, as double buds of the same or different ages as shown in F1gs. 5 and 7 , or they may arise from the neck of an older blid, as shown in Fig. 8. Some buds arise very close to older ones, but still in the larval wall. This can be consldered as a modification of the last way. It appears as if the buds are formed from both layers of the larval wall. F1g. 12 represents a very young bud. The Inner layer of the larval wall by growth is folded in to form the bud. The cells of this layer are now cublcal in form, and the protoplasm stains heavily showing that the cells are active. Beneati this layer is a mass of protoplasm contalning a number of nucle1, but the cell boundaries are not distinct. This mass of cells is formed by the division of the ectoderm cells. The ectoderm cells are vacuolated, and, since division takes place throlich the center of the protoplasm, the result would be the fornation of a vacuolated and a non-vacuolated cell. Further division of the latter forms the inass of cells. The nuclel are slightly larger than those in other cells, and the nucleoll are larger and appear branched. There is every indcation of activity in these cells also. As develoment goes on these cells become enclosed within the bud where they form a layer of columnar cells, as is show in Fig. 8. Sornetines vacuoles appear in the bud, but this is due, perhaps, to a very papid growth of the inner layer of the larval sac in forming the bud, and a slow- 

er development of that part derived from the ectoderm. These vacuoles soon disappear.

After the buds are formed, they gradualy separate from the older bud, near which or from which they originated. Their final position is usually to the side of the older/and a little farther up on the larval wail. The larger and consequently the older polypldes or buds are located closer to the pole of the non-ciliated region. The oral side of the polypide is always toward the larval wall. while the anal side is directed away, and points toward the center of the larval sac. In fully formed polypldes their long axis is about paraliez with the lonf axis of the larval sac.

All of the buds observed, formed on the oral side of the polypide or older bud. They arise elther to the left, to the rlent, or directly above the neck of the older bud. In two or three cases, certain structures were developed on the anal side Which had the appearance of buds, but were very small.

The primary buds, which are two in number, separate very rapidly, and take positions either 180 or 90 degrees apart. but In the same plane. The secondary buds arise close to the primar1es. The secondaries may be found, one to the left of either primary, or one to the right of either primary. In some larvae one secondary arises to the right of one primary and the other to the left of the other primary. In this last type the primaries separate only 90 defrees, while in the other two, the primaries separate 180 degrees. In the two former cases the secondaries separate 180 degrees from each other, thus makinf thelr positions 90 degrees from the primarles. In the latter case, the secondarles are located 90 degrees from the primarles, but are only 90 de- 

grees from each other. The two primaries and two secondaries are situated almost in the same plane, and their positions are such that each of the four polypides represents the corner of a square. In some cases the secondartes arise before the primaries are 180 defrees apart, and sonetimes afterward. This statement applies where the primarles separate only 90 degrees as well. The same final relations obtain in either case. In some cases two buas are formed one on either side of the primaries, but one is always smalier than the other.

In the same larva, in Eeneral, the third pair of buds bear the same relation to the secondaries as the secondaries bear to the primaries. This budding in pairs continues for a time, and then four buds arise at about the same time, one near each of the primarles and secondaries.

The buds are regular in their development, and bear definite relations to the buds next older, near which they originate. When the buas become full grown, there appears an opening on the nonclliated surface of the larva just at the place where the buds are attached. The outer layer of the larva becomes invaginated, and its cells in the invaginated part are filled with protoplasm, and arranfed in the form of a ring. This invagination is not deep, and the celis on the summit are vacuolated, and at last separate, making the passage to the outside complete. Figs. 13 and 14 represent the formation of this opening. The sections were cut a little obliquely, and so the entire passage does not appear in one section. Four of these openings were present in the older larvae. 



\section{BIBIIOGRAPHY 。}

Braem, F.

97. Die geschlechtliche Entwickelung von Plumatella fungosa. Zoologica, herauss.v. Chun, Hef't 23 stuttgart.

108. Die geschlechtliche Entwickelung von Fredericelia sultana nebst Beobachtunen über die weitere Lobensgeschichte der Kolonien. Zoologica, herausg. v. Chun, Heft 52. Stuttgart. Davenport, C. B.

191. Observations on Budding in Paludicella and some other Bryozoa. Bull. Mus. Comp. Zoöl. at Harvard Colıege. Vol 22: $1-114$.

"90. Cristatella: The Orisin and Development of the Individual in the Colony. Bull. Mus. Comp. Zool. at Harvard College. VOI. 20 : $101-151$.

Kraepelin, K.

Die Deutschen süsswasser - Bryozoen.

II Ent. Teil. (monosraph). 



\section{EXPLANATION OF FIGURES.}

All figures were drawn with the aid of a camera lucida from preparations of Pectinatella.

\section{Abbreviations .}

$$
\begin{aligned}
& \text { An. = anus } \\
& \mathrm{b}_{\text {. }}=\mathrm{bud} \\
& \mathrm{b}_{1} \text {. = daughter bud } \\
& \text { c. = cilia } \\
& \text { ca. = caecum } \\
& \text { c.f. = cavity of fold } \\
& \text { coen. = coenocoel } \\
& \text { c.p. = ciliated part of larval sac } \\
& \text { 1. 1. = inner layer } \\
& \text { inv. = invagination } \\
& \text { kinp. } \mathrm{drm} .=\text { kamptoderm } \\
& \text { 1oph. = lophophore } \\
& \text { lu.gm. = Iumen of bud } \\
& \text { n.p. = non-ciliated part } \\
& \text { o. = external opening in larval sac } \\
& \text { oe. = oesophares } \\
& \mathrm{P}=\text { Primary bud } \\
& \mathrm{p}=\text { Polyp } 1 \mathrm{de} \\
& \text { r. = rectum } \\
& \text { r.f. = ring fold } \\
& \mathrm{S}=\text { secondary bud } \\
& \text { st. = stomach }
\end{aligned}
$$



$T=$ Third bud

$t_{\text {. }}=$ tentacle

w. = wall of larval sac

$v_{\text {. }}=$ vacuole

Fig. 1. The entire larva. An optical section, showing the relation of parts of the larval sac, and also the position of polypides. $x 81$.

Fig. 2. A polypide in position with a part of larval wall to the right. $\times 270$.

Fif. 3. A section of the larval sac in the dome-shaped portion. Cross section, 141 in thickness. X 570 .

Fig. 4. A lonfitudinal section through the ring fold. 14 X 570 .

Fig. 5. A section of the larval wall in the non-ciliated portion, showing the formation of two buas at once. X 570 .

Fif. 6. A section of the larval sac in the dome-shaped portion of an older larva. Longitudinal section, showing the modified ectoderm, and the peculiar. structures at the bases of the cilia. X 570.

F1s. 7. Two buds formine at the same place. One is just a little older than the other. $\times 570$.

Fig. 8. A section showing the formation of a young bud from the neck resion of the older one. X 570 .

Fig. 9. A young bud developing directly from the wall of the larva at some distance from an older bud. X 570. 

Fig. 12. A very young bud developing very close to an older one. This shows clearly the way in which buds arise. $\times 570$.

F15. 13. Shows the invagination forming the opening through Which the 1ophophores may be protruded. The summit of the invaginated part is vacuolated. The entire passage way does not show here because the sections were cut obliquely - x 570.

F1g. 14. A section of the same larva as that represented in Fig. 13. Here the opening at the outside does not show, but the opening at the summit of the invatination does. The lophophores are represented diagrammatically in this figure. X 570.

Figs. 15 \& 16. A diagramatic representation of the buds in a single larva. The relative size and position of buds are represented by the circles on the inside of the large circle.

Fig. 17. A younger stage in the developinent of the buds. In this larva the secondaries orifinated to the right of the primaries.

Fig. 18. Represents the secondaries arising to the left of the primaries.

Fis. 19 \& 20. One secondary arises to the right of the primary and one to the left of the other primary. 

FIg. 1 .

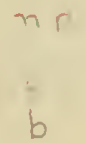

Fig. 2

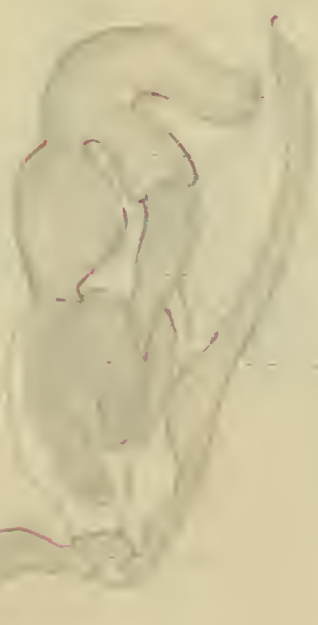



Fig. 3 .
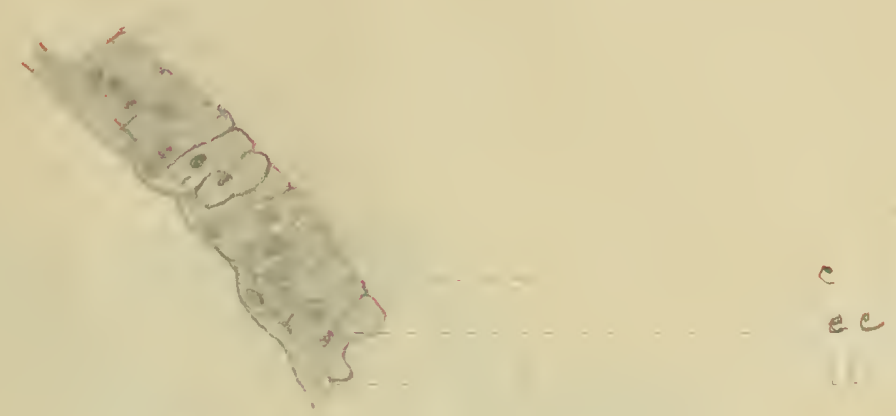

Fig. 4.

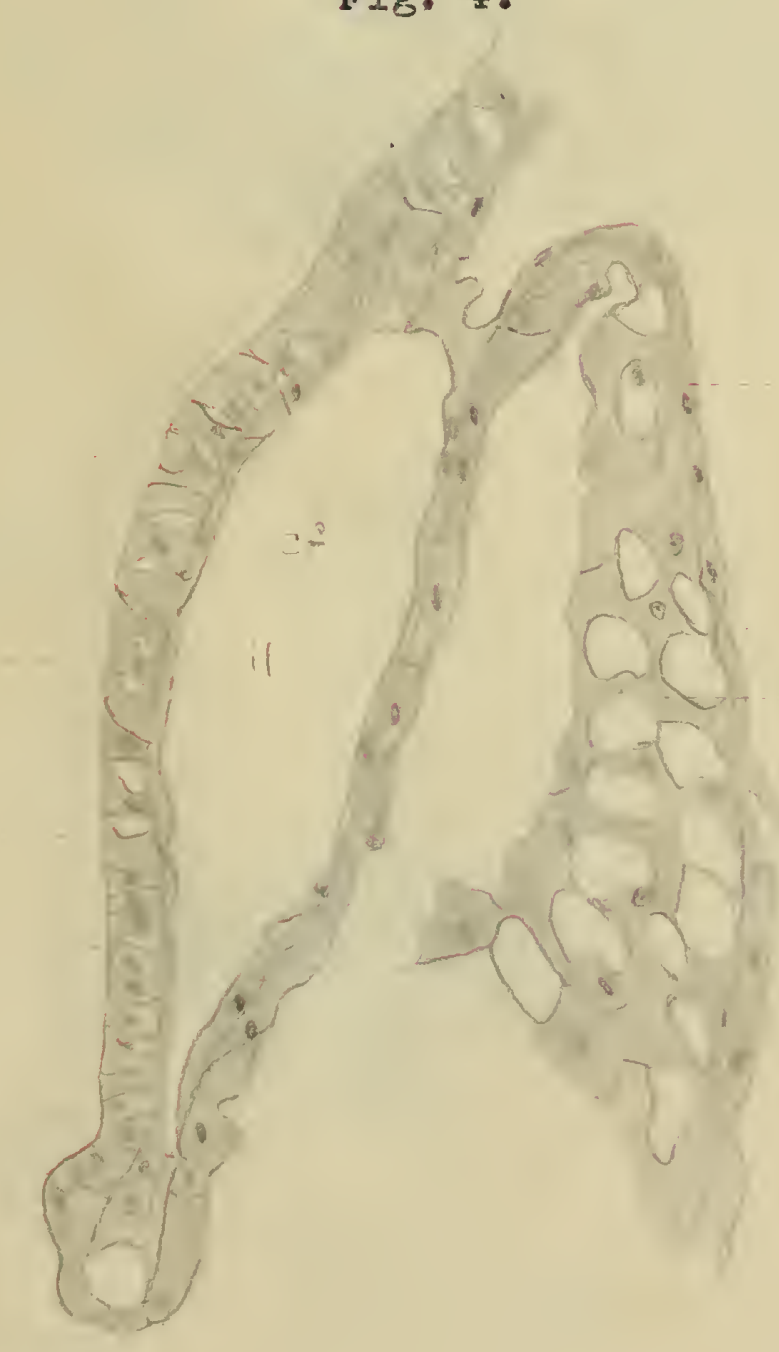



Fig. 5.

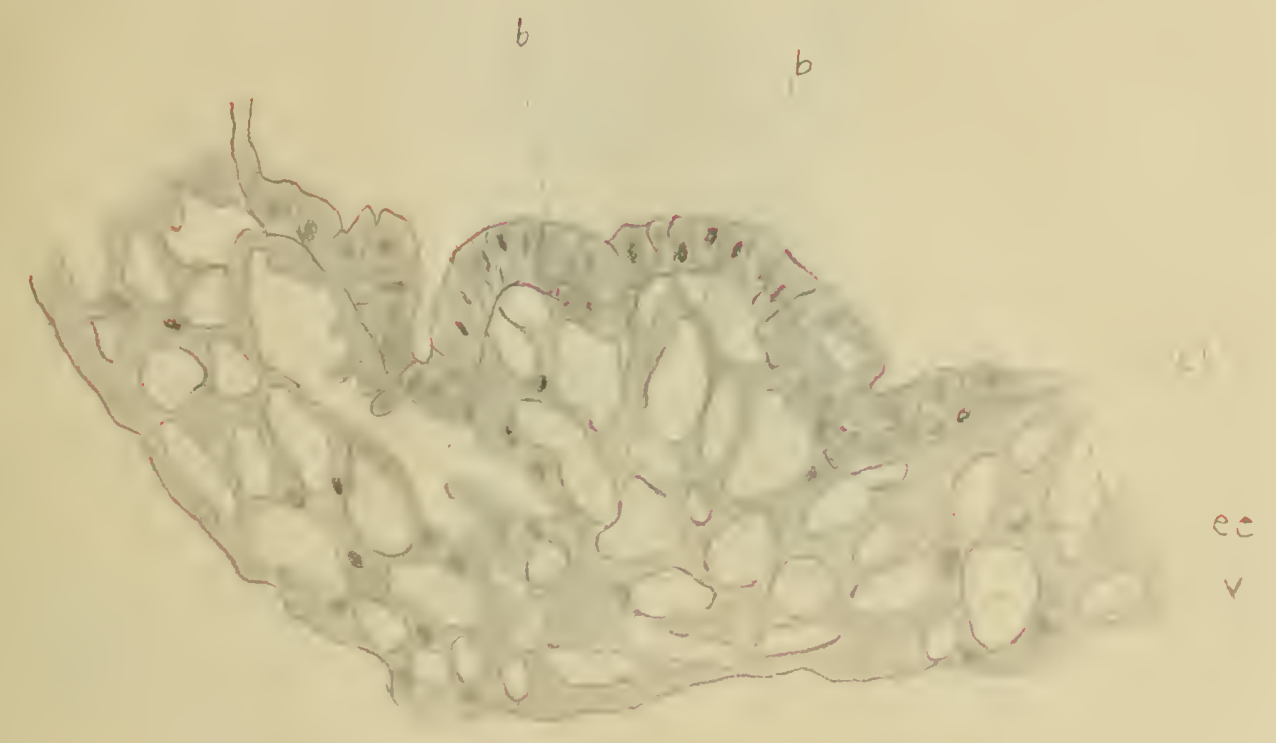

Fig. 6 .

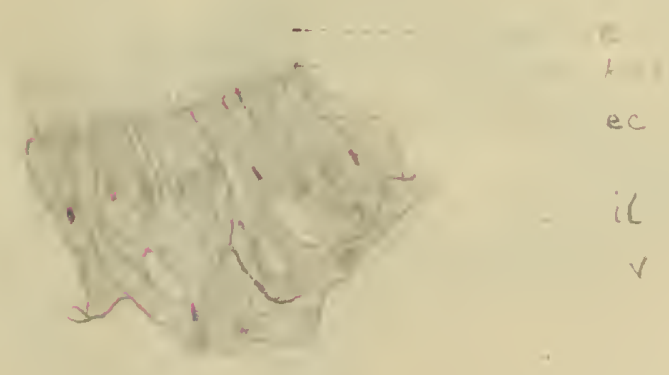



F1g. 7 .

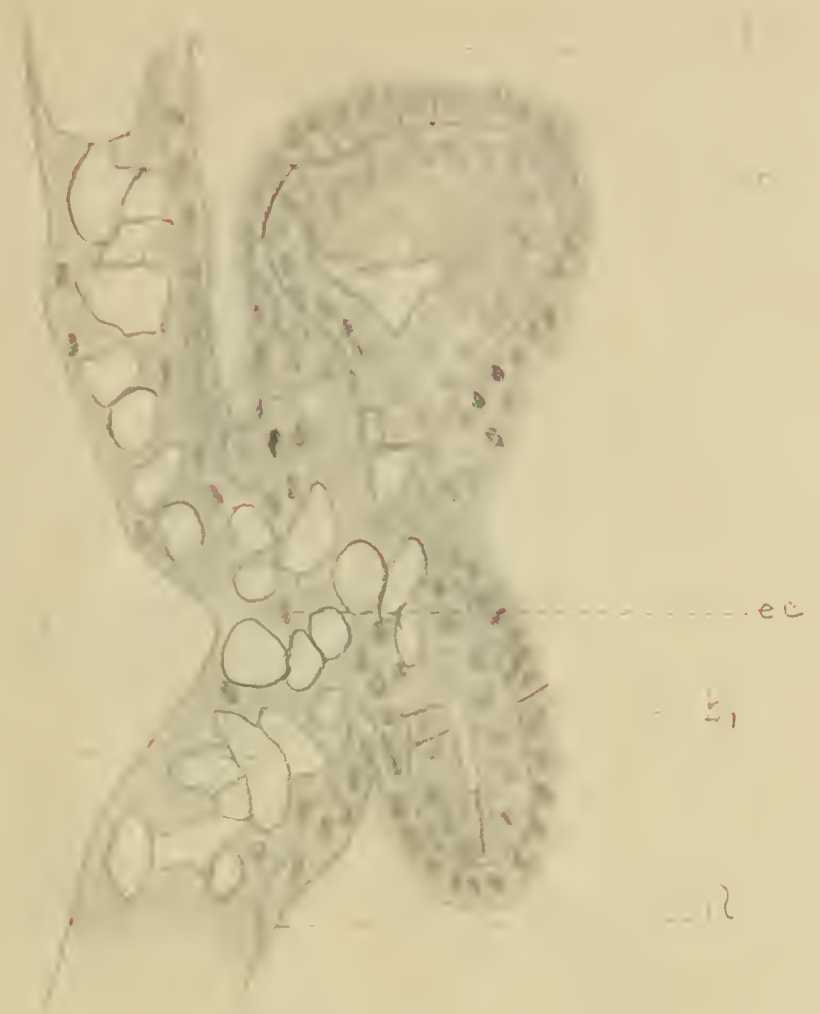

Fig. 8 .

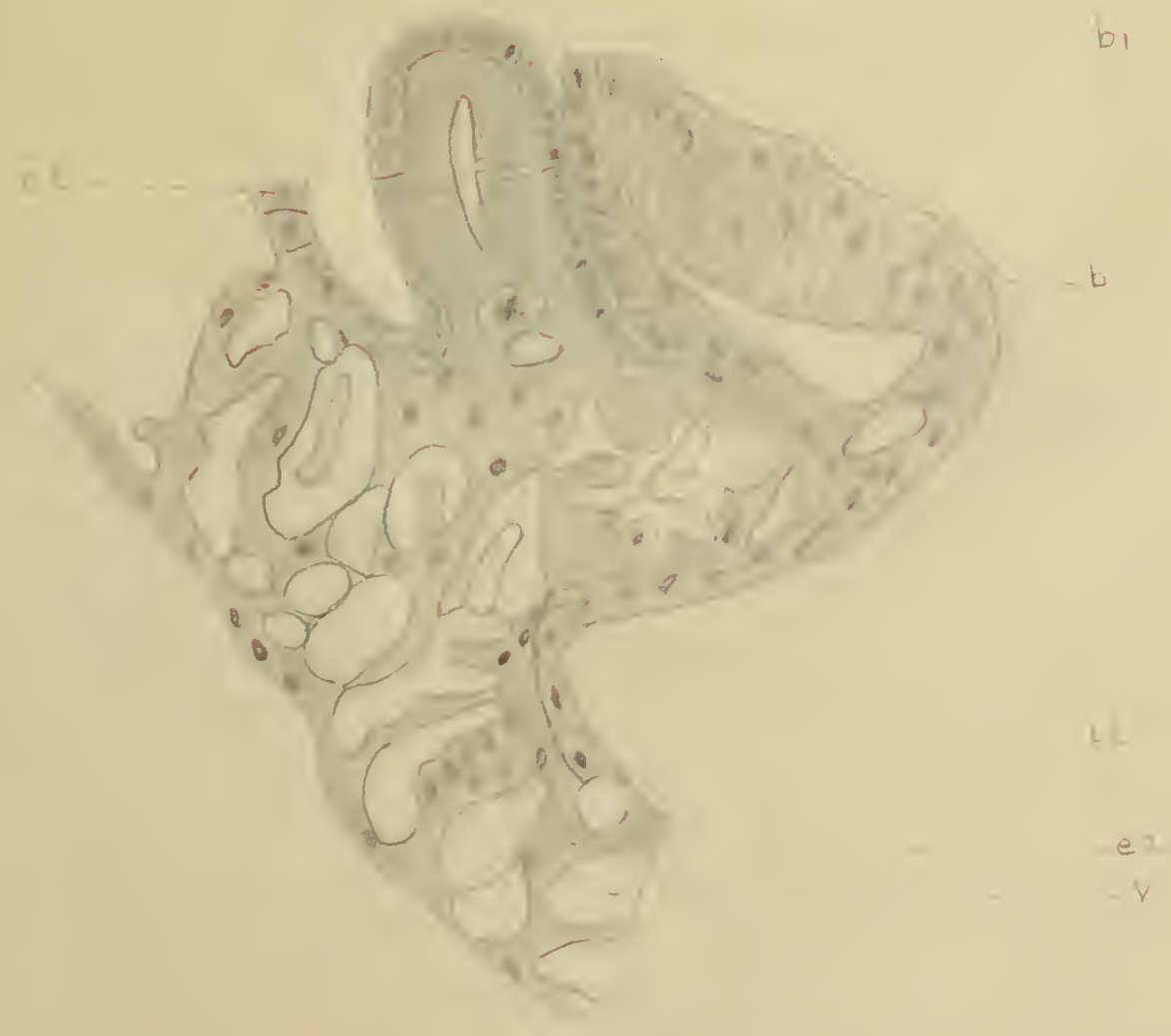



Fig. 9 .

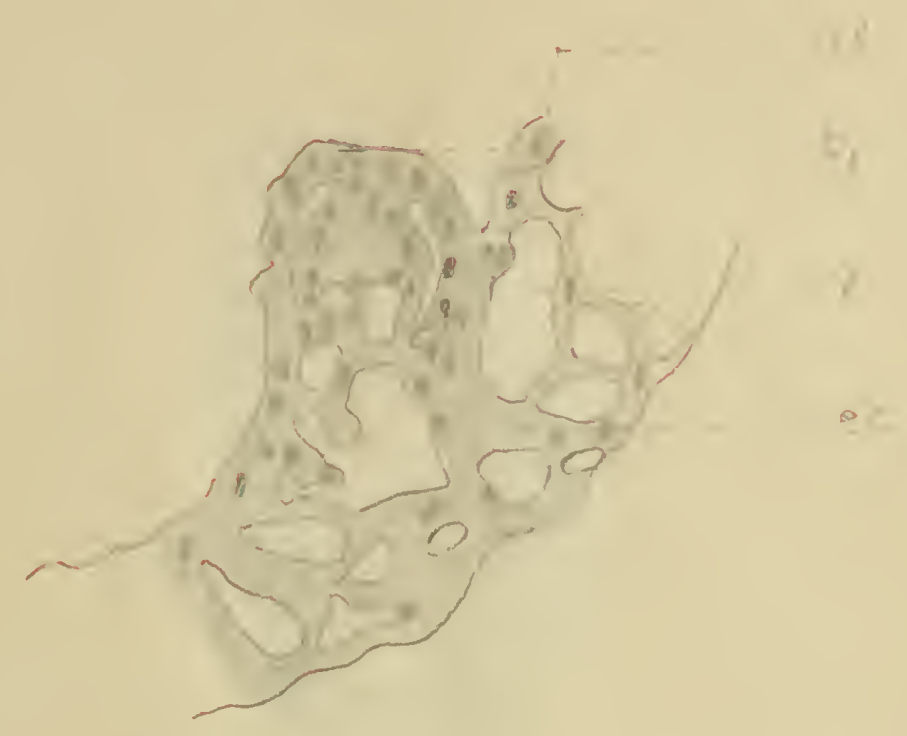

F1g. 12 .

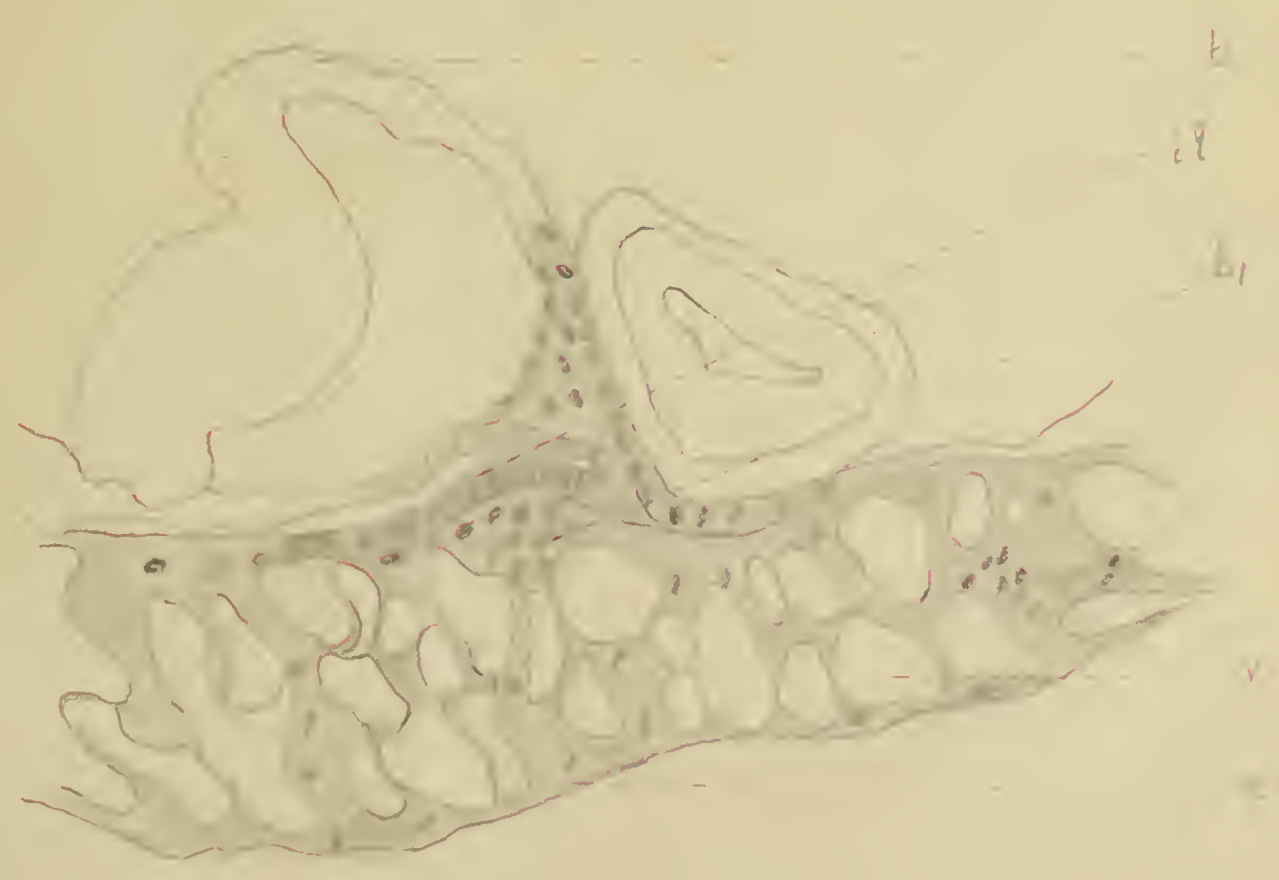



Fig. 13.

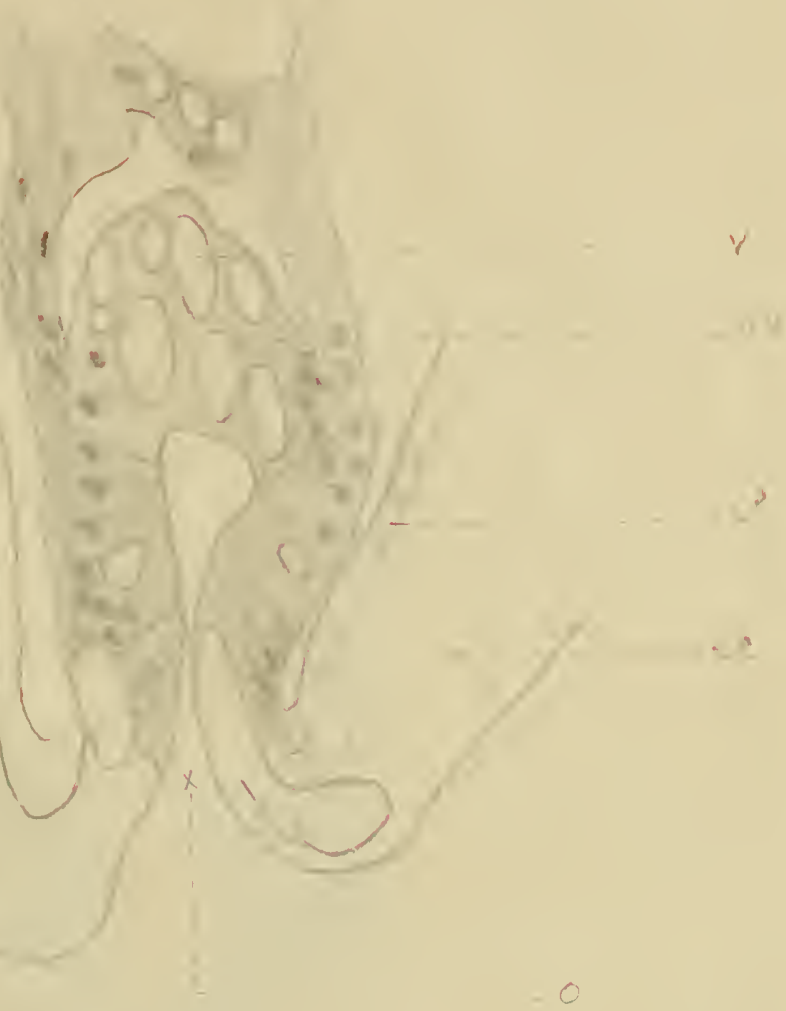



F18. 14 .

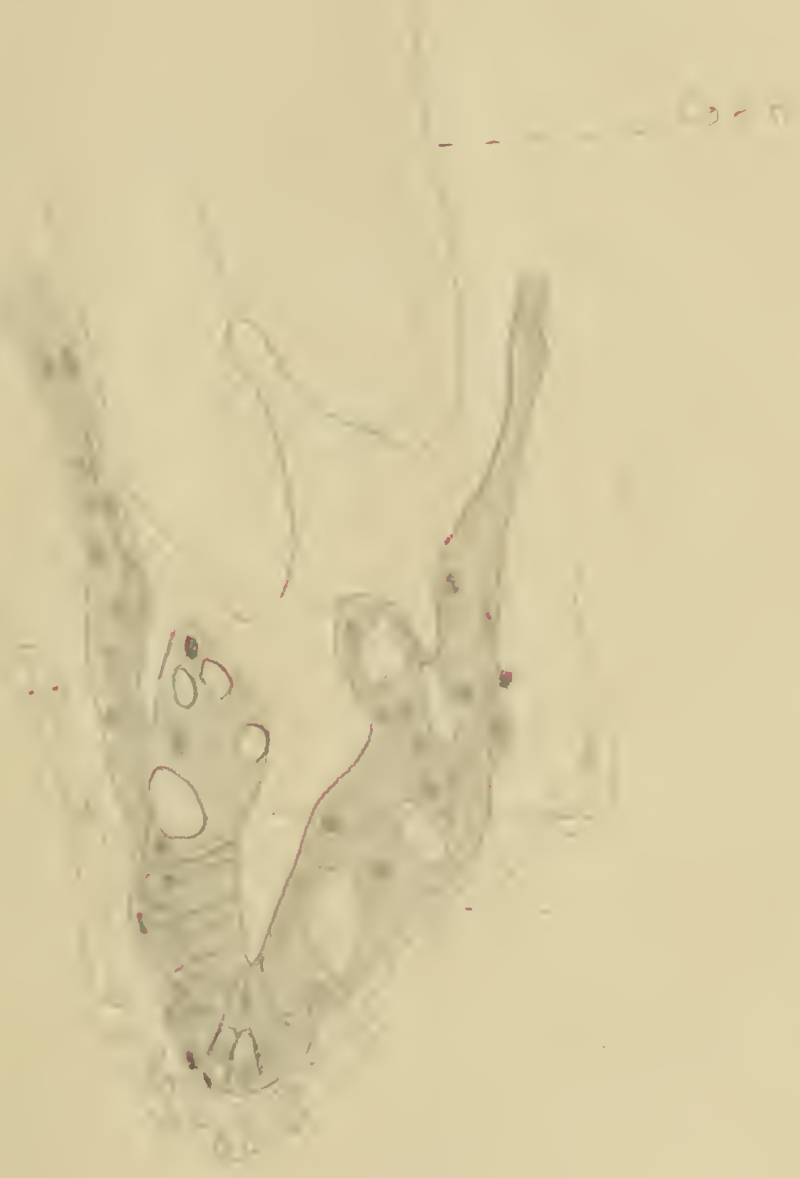



Fig. 15.

Fig. 16.

F18. 17. 

F18. 18.

F1g. 19.

Fig. 20. 


